\title{
$\bullet$ \\ Unani Perspective of Nausea and Vomiting in Pregnancy: A Literary Research
}

\author{
IJCRR \\ Section: Healthcare \\ ISI Impact Factor \\ (2019-20): 1.628 \\ IC Value (2019): 90.81 \\ $\operatorname{SJIF}(2020)=7.893$

\section{Arshi Anjum ${ }^{1}$, Kouser Fathima Firdose ${ }^{2}$}

'Lecturer, Department of 11 mul Qabalat wa Amraze Niswan, State Unani Medical College, Prayagraj, India; 'Lecturer, Dept of 11 mul Qabalat wa

Amraze Niswan, National Institute of Unani Medicine, RGUHS, Bangalore, India.

\section{ABSTRACT}

Nausea and vomiting (Qay'al-haml) are considered atypical and almost inevitable feature of pregnancy. Concern about the harmful effect of medication on the fetus may cause many women not to seek treatment or to try alternative therapies for nausea and vomiting. The only medicine that is FDA-approved for Nausea and vomiting in pregnancy is doxylamine-pyridoxine combination; has reported side effects like somnolence, headache, dizziness, dry mouth, and hypersensitivity. According to Unani scholars, nausea and vomiting in pregnancy are mostly due to the accumulation of morbid material in the stomach. It is relatively uncommon in the male fetus. The objective of the study is to search classical literature of nausea and vomiting in pregnancy (Qay'al-haml) and to correlate with modern literature. The classical Unani sources viz., Al-Qanun fi'l Tibb (Canon of Medicine), Iksir-i-A ‘zam, Al Hawi fi'l Tibb (Continens Liber), Tarjuma Kamil al-Sana'a al-Tibbiyya, Dhakhira Khawarizm Shahi, and Tibbi-Akbar were reviewed. Further, different search engines were also browsed on the website to explore recent studies. Various Unani drugs are mentioned for the treatment of qay'al-haml including gulqand, sikanjabeen sada, sharbat anar sheerin, sikanjabeen lemooni, jawarish anarain, mastagi, ilaichi etc. In this literary research, an effort has been made to focus on the various causes, diagnosis and management of nausea and vomiting in pregnancy by Unani system of medicine. Some herbs and Unani compound formulations used in the treatment of qay'al-haml have also been highlighted.

Key Words: Nausea, Fetus, Doxylamine-pyridoxine, Qay'al-haml

\section{INTRODUCTION}

Pregnancy and childbirth are basic life events vital to the maintenance of humankind and thus are considered physiological processes. The most common complication affecting women in the first trimester is nausea and vomiting of pregnancy (NVP), ${ }^{1}$ occurring in $44 \%$ to $89 \%$ of pregnant women. ${ }^{2}$ Nausea and vomiting in pregnancy is defined as the symptom of nausea and/or vomiting during early pregnancy when no other cause is responsible for it, ${ }^{3}$ with an onset which often begins between the fourth and seventh week after the first missed menstrual period and resolves by the 20th week of gestation. ${ }^{4}$ It is a syndrome caused by the complex interaction of genetic and environmental factors beginning during a unique period: organogenesis. ${ }^{2}$ The risk factors of NVP include race, baby's sex, young maternal age, multifetal gestation, low income, low education level, history of premenstrual syndrome, and unwanted pregnancy. ${ }^{5}$ The severity of NVP has a broad spectrum therefore it is critical to have a graded scale to track the severity of symptoms as a guide to determine the appropriate treatment and response to treatment. In 2002 Ebrahimi et al. introduced the PregnancyUnique Quantification of Emesis (PUQE) scoring system. The updated PUQE score assesses the severity of NVP based on three physical symptoms: nausea, vomiting, and retching over the previous 24 hours. ${ }^{6}$

\section{MATERIAL AND METHODS}

The classical Unani sources viz., Al-Qanun fi'l Tibb (Avicenna's Canon of Medicine), Hakeem Azam khan's Iksiri-A 'zam, Al Hawi fi'l Tibb (Rhazes's Continens Liber), Tarjuma Kamil al-Sana a al-Tibbiyya, Jurjani’s Dhakhira Khawarizm Shahi, Jamiul Hikmat, Khazainul advia, Afadae Kabeer and Ghana Muna etc reviewed and searched for terms including qay'al-haml, qay, matli, hamila ke awarizat, su'i-mizaj-i-mida, zofe mida, zofe jigar etc. for aetiology, differential diagnosis, management.

\section{Corresponding Author:}

Dr. Arshi Anjum, Flat no.504-B, Mosam Vihar, IIIT Road, Kallindipuram, Prayagraj U.P. 211012, India.

Mobile: 9108635045; Email: arshianjum63594@gmail.com

ISSN: 2231-2196 (Print)

Received: 13.08 .2020
ISSN: 0975-5241 (Online)

Revised: 18.10 .2020
Accepted: 05.11 .2020
Published: 16.01 .2021 
Major scientific databases namely Pubmed, Science Direct and Springer, Google scholar, Orchid, SCOPUS, Crossref, CAS Abstracts, Publons, CiteFactor, Open J-Gate, ROAD, Indian Citation Index (ICI), Indian Journals Index (IJINDEX), Internet Archive, IP Indexing, Scientific Indexing Services, Index Copernicus etc were searched for the most recent information regarding the modern concept of NVP, risk factors, aetiology and pharmacological management etc. using keywords nausea, vomiting, retching. Same databases were also searched for evidence of scientific work done on Unani drugs in NVP by using terms zanjabeel, limoo, na'na, behi, hel etc.

Approximately 15 books and 100 papers were browsed, some of them based on prevalence and studies, other papers were based on contemporary treatment, the complementary and alternative treatment of nausea and vomiting in pregnancy.

\section{AETIOLOGY}

Aetiology of NVP remains unknown; ${ }^{7}$ however various theories have been proposed for the aetiology of NVP, but a combination of several factors are probably involved (Table 1).

\section{Table 1: Factors involved in the aetiology of NVP}

\begin{tabular}{|c|c|}
\hline $\begin{array}{l}\text { Evolutionary } \\
\text { perspective }\end{array}$ & $\begin{array}{l}\text { Normal levels of NVP protect pregnant women } \\
\text { and their foetuses against harmful substances } \\
\text { in food. }{ }^{8} \text { This maternal and embryonic protec- } \\
\text { tion hypothesis takes into account primary } \\
\text { symptoms of nausea and vomiting, as well as } \\
\text { secondary symptoms such as heightened ol- } \\
\text { faction, that may be related to increased hor- } \\
\text { mone levels. }{ }^{9}\end{array}$ \\
\hline
\end{tabular}

Genetic NVP and HG show patterns of familial aggregation. A higher risk of severe NVP/HG is found among women with mothers and/ or sisters who have experienced severe NVP/ HG. Monozygotic female twin pairs are found to be more concordant than dizygotic female twin pairs concerning experiencing NVP. ${ }^{8}$

Endocrine Hormonal changes occurring in pregnancy are thought to be part of the aetiology of NVP and HG, and the most commonly proposed hormones involved include the hCG, oestrogen, progesterone and thyroid hormones.

- hCG: The most implicated factor is hCG. when hCG concentration increases in body, nausea and vomiting also increase. Between 12-14 weeks of pregnancy hCG is its peak concentration, at the same time, there are more chances of NVP. ${ }^{10}$
- Oestrogen and progesterone: Estradiol \& progesterone increases early in pregnancy and slowly rises throughout the remainder of the pregnancy.

- TSH: Since hCG and TSH are structurally related, the observed association with hyperthyroidism may be explained by characteristics facilitating highly stimulating properties of the thyroid gland among women with HG. However, since hyperthyroidism itself is seldom a cause of nausea and vomiting, the focus is switched back to hCG. ${ }^{8}$

Psychological Pregnant women with stress and emotional factors tensions often have this condition. ${ }^{12}$

Gastric dys- Changes in gastric rhythmic activity may rhythmias contribute to NVP. The intensity of nausea is significantly greater in pregnant women with gastric dysrhythmias than in those with normal electrogastrographic patterns. ${ }^{8}$

\section{UNANI CONCEPT}

In Unani classical literature, the term coined for nausea and vomiting in pregnancy is Qay'al Haml. According to Unani scholars, the cause of NVP is morbid material which accumulates in the cavity of the stomach or the muscles or layers of the stomach ${ }^{13,14}$ This material can be bilious, phlegmatic (often balgham-i- milh) ${ }^{13,15}$ or black bile. ${ }^{13}$ More often nausea in pregnancy is due to bile, although bile is not a morbid material. ${ }^{16}$ Bilious material causes irritation in the stomach and hence vomiting. Thick and viscous material firmly accumulated on the surface of the stomach produces nausea and retching not vomiting.

\section{Differential diagnosis of Qay'al-ham/14}

1. Non- obstetrical causes of vomiting are- Haida, Su'- $i$ hadm, Waja-al mi'da, Quruh al-Mari wa Litha, Inqilab al-mi'da, Waram al-jigar, Qulanj, Waram al-tihal, Humma, Waram al-gurda, Deedan

If vomiting is not due to these diseases, then itself is a disease.

2. Enquire about diet before vomiting, improper food habit, rotten food then cause is attributed to fasad-i -ghidha. (food poisoning).

3. If vomiting is not persistent and is associated with disorders of the liver, gall bladder, spleen and uterus or any other organ of the body then the cause of vomiting is due to these disorders.

4. Su'-i-mizaj

- Su'-i-mizaj sa'da: If no other cause of vomiting is diagnosed then it indicates that it is solely due

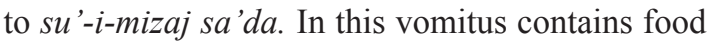
particles but no other khilt. Urine is clear and diluted. 
a. Su'-i-mizaj harr sa'da: Increase thirst, dry mouth, burning sensation in the stomach, hadam qawi, hot drinks are harmful.

b. Su'-i-mizaj barid sa'da: Decrease thirst, weak digestion, pale face, soft stool, increase appetite, belching.

c. Su'-i-mizaj ratb sa'da: Coldwater, wet and moist things are harmful. Dry food and a small quantity of food is beneficial, increase salivation, nausea.

d. Su'-i-mizaj yabis: Dry tongue, constipation, dislikes dry foods.

- $\quad S u$ '-i-mizaj Maddi: If manifestations of any khilt (humour) are present, then the type of vomiting depends upon khilt (humour) present in vomitus. If vomitus contain food particles along with khilt, then the cause of vomiting is su'-i-mizaj maddi and urine is viscous, turbid.

a. Su'-i-mizaj safravi: Bitterness in mouth, nausea, yellow urine, belching. b. Su'-i-mizaj saudawi: All signs of su'-i-mizaj yabis including increase appetite, improper digestion, dark yellow pigmentation of the face, urine is a viscous and dark colour.

c. Su'-i-mizaj balghami: decreased appetite, fatigue, nausea, increased salivation, pale face, urine is white, vomitus contains phlegm.

5. With manifestations of cold temperament, there is tension in ribs and increased flatulence- then the cause is riyah.

6. Stretched ribs along with nausea, burning sensation in the stomach, stool with bad odour- the cause is then attributed to spoilt food.

\section{MANAGEMENT}

\section{Pharmacological treatment ${ }^{17-19}$}

The following table 2 shows the treatment of drug with their dose and mode of action.

Table 2: Pharmacological treatment with dose and mode of action

\begin{tabular}{|c|c|c|c|c|}
\hline Drug Name & Category & Dose & Mode Of Action & Any Other Remark \\
\hline $\begin{array}{l}\text { Doxylamine suc- } \\
\text { cinate }\end{array}$ & $\begin{array}{l}\text { Antihistamine -pyri- } \\
\text { doxine hydrochloride } \\
\text { combination }\end{array}$ & 2omg, Orally & $\begin{array}{l}\text { Interrupt the histamine } \\
\text { pathway }\end{array}$ & $\begin{array}{l}\text { In } 2013 \text { US FDA approved } \\
\text { doxylamine succinate ( } 20 \mathrm{mg} \text { ) } \\
\text { an antihistamine and pyridoxine } \\
\text { hydrochloride ( } 20 \mathrm{mg} \text { ) combina- } \\
\text { tion for the treatment of NVP }\end{array}$ \\
\hline $\begin{array}{l}\text { Meclizine, hy- } \\
\text { droxyzine,dimen- } \\
\text { hydrinate, }\end{array}$ & Antihistamines & $\begin{array}{l}25 \mathrm{mg}, 50 \mathrm{mg} \text { and } 50 \\
\text { to } 100 \mathrm{mg} \text {, respectively, } \\
\text { every } 4-6 \text { hours orally }\end{array}$ & $\begin{array}{l}\text { Block the histaminic re- } \\
\text { ceptors in both vestib- } \\
\text { ular-system }\left(\mathrm{H}_{1}\right) \text { and } \\
\text { chemoreceptor trigger } \\
\text { zone }\left(\mathrm{H}_{2}\right) \text { receptors }\end{array}$ & $\begin{array}{l}\text { Both 1st and 2nd generation anti- } \\
\text { histamines are safe in pregnancy. }\end{array}$ \\
\hline Metoclopramide & Promotility agents & $\begin{array}{l}\text { 1omg orally, every } 6 \\
\text { hours }\end{array}$ & $\begin{array}{l}\text { increase LES pressure } \\
\text { and gastric transit }\end{array}$ & -------------------- \\
\hline Phenothiazine & Antipsychotics & 3omg & $\begin{array}{l}\text { It interferes with dopa- } \\
\text { mine to bind its own } \\
\text { receptors. }\end{array}$ & -------------------- \\
\hline Ondansetron & $\begin{array}{l}\text { serotonin receptor } \\
\text { antagonist }\end{array}$ & $\begin{array}{l}\text { 4-8mg IV, every 8-10 } \\
\text { hours }\end{array}$ & $\begin{array}{l}\text { Block the signals gener- } \\
\text { ated by vomiting centre } \\
\text { in brain }\end{array}$ & --------------------- \\
\hline
\end{tabular}

\section{Unani management}

Usoole ilaj (Unani principles of treatment) may be divided into following sub headings: ${ }^{20}$

1. Ilaj bi'l ghidha (Dieto-therapy)

2. Ilaj bi'l tadbeer ( Regimental therapy)

3. Ilaj bi'l Dawa ( Pharmacotherapy)

4. Ilaj bi'l yad (Surgery)

\section{Ilaj bi'l ghidha (Dieto-therapy) ${ }^{14,19,21}$}

1. Light diet is advisable which provides strength to the stomach and stops vomiting example titar, chuza murg.

2. Advise empty stomach- rube reebas, rube hasram.
3. Eat a pomegranate in the early morning and lies on the bed for 1 hour.

4. Avoid hot and warm food.

5. Avoid sweet dishes.

\section{Ilaj bi'l tadbeer (Regimental therapy) ${ }^{21,22}$}

1. Moderate walk, light exercise.

2. Dimad on the abdomen- badiyan alone or along with qinnab and sharab Rehani or grape flowers and gulnar or barge kiram, gulnar and karafs Roomi, tukhme razyana

\section{Ilaj bi’l Dawa (Pharmacotherapy) ${ }^{16,19,21,22}$}


Nausea and vomiting in pregnancy is usually self limiting, if it is not alleviated advice mullaiyanat, muqawwiyat -almi'da wa a'da ra'isa.

$1 \mathrm{~g}$. Gule surkh $9 \mathrm{~g}$, gule gaozaban $9 \mathrm{~g}$, sapistan $10 \mathrm{~g}$ seeds, unnab $7 \mathrm{~g}$, khubani $7 \mathrm{~g}$, aloo bukhara 11g. All these drugs are soaked overnight in gulab jal and kewda. To this maghze khyare shambar $72 \mathrm{~g}$, sheere khisht, gulqand each $48 \mathrm{~g}$ are added, grind the mixture and filter and give orally with $7 \mathrm{~g}$ roghane badam.

2. Qurs- qaranphal, quste sheerin, jooz, sak, mastagi, agar, ilaichi, kababa each of equal weight mix with aabe-tursh or aabe-bihi and make qurs(tablet). This tablet is a very useful formulation for vomiting and craving for food.

3. Gulqand and sikanjabeen sada $24 \mathrm{~g}$ is beneficial or sikanjabeen lemooni or murabba leemu kaghzi.

4. Oral intake of sharab rehani asfar is beneficial.

5. Rewand chini before and after meal.

6. Gile armani, mix with sharbate meeba.

7. Joshanda of assiur ra'as( lal sa'ag) before and after meal.

8. Joshanda shibt alone and along with shahed musaffa is beneficial in NVP.

9. Mixture of oode kham and mastagi is also beneficial.

10. For pregnant women with harr mizaj - sharbate turanj, sharbate leemu, sharbate ghura and sharbate anar is beneficial.

11. Safoof barai mitli- loung, qust sheerin, mastagi, jaipal, choti ilaichi, agar, kabab chini, sak each of equal weight are finely powdered.

Dose- four and half gram with aabe-saib sheerin.

12. If vomiting is due to fasad-i-ghidha or safra then oral intake of sikanjabeen $50 \mathrm{ml}$ and salt $25 \mathrm{mg}$ in water is effective as it helps in stomach wash, then drink arqegulab $120 \mathrm{~g}$, and sharbate anar sheerin $25 \mathrm{ml}$.

13. If vomiting is due to gastric ulcers then dimad of radia'at and sandal safaid, kishneez khushk is effective

\subsection{Mamoolate matab ${ }^{13}$}

- Tukhme khurfa, tukhme khyarain, zarishk, munaqqa each $3 \mathrm{~g}$, aloo bukhara 5, make sheera of all these in arqe-gulab $60 \mathrm{ml}$, drink after adding sharbate tamar hindi $12 \mathrm{ml}$.

- Tabasheer, zareward, kishnnez khushk, post samaq, anar dana biryan each $1 \mathrm{~g}$, after grinding and straining add sharbate ghura $25 \mathrm{ml}$, sikanjabeen lemooni 25 $\mathrm{ml}$ and take orally.

- Jawarish anarain $7 \mathrm{~g}$ with zarishk $3 \mathrm{~g}$, sheera pudina $3 \mathrm{~g}$, sheera dana ilaichi $3 \mathrm{~g}$ in arqe-gawzaban $150 \mathrm{ml}$ with sharbate anar $25 \mathrm{ml}$ orally in the morning and evening.

- Zarishk, samaq, anardana, dana heel finely grinded and given with sikanjabeen lemooni $25 \mathrm{ml}$ half an hour after food.

\section{EVIDENCE BASED UNANI MEDICINAL PLANTS EFFECTIVE IN NVP}

\section{Punica granatum (Pomegranate)}

The pomegranate belongs to plant family Lyhraceae ${ }^{23}$ it is known as "Anar"24 (Figure 1), it's said to be cold and wet. a way to treat NVP in Unani medicine is keeping pomegranate seeds and mint within the mouth ${ }^{25,26}$. One study evaluated the results of pomegranate and spearmint syrup on NVP. No health hazards are reported following the right administration of designated therapeutic dosages. ${ }^{27,28}$

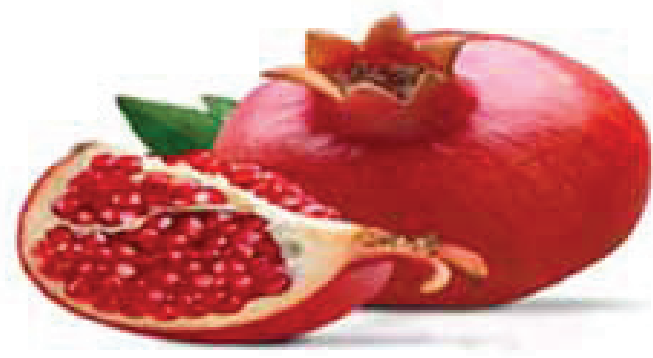

Figure 1: Punica granatum.

\section{Citrus Limon (Lemon)}

The lemon is a plant of the family Rutaceae. It is known as "Limoo" ( figure 2) and has been used as an efficacious remedy for NVP in unani system of medicine, cold and dry in temperament. Lemon is rich in phenolic compounds, vitamins, minerals, fiber, and carotenoid oil and has analgesic, antiseptic, anti-emetic, and diuretic properties. In a study lemon aromatherapy led to a significant reduction in NVP compared to placebo $^{29}$

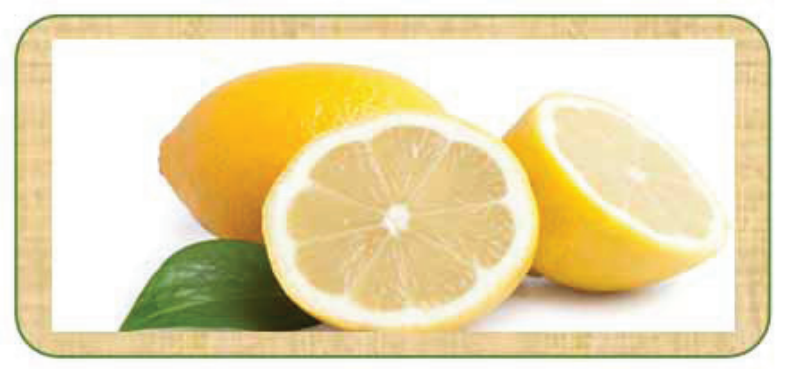

Figure 2: Citrus limon.

\section{Mentha Piperita (Mint)}

Mint is a plant in the family Lamiaceae (Figure 3). The leaves of mint known as " $\mathrm{Na}$, $n a$ " in Unani have also been used in the treatment of NVP. It is said to be warm and dry in temperament. In a double-blind RCT, the effect of aromatherapy with pure mint essential oil versus placebo was evaluated in 60 pregnant women with NVP. ${ }^{2,24}$ 


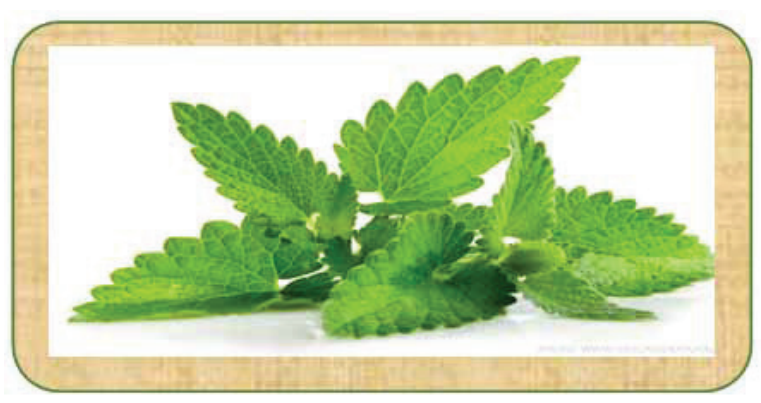

Figure 3: Mentha Piperita.

\section{Elletaria cardamomum (Cardamom)}

Cardamom is a member of the family Zingiberaceae (Figure 4). Cardamom (Elletaria cardamomum), known as "Hil" or "Hel", warm and dry. Aromatherapy with inhalation of cardamom oils is effective in relieving nausea caused by chemotherapy in patients with cancer. Ozgoli et al. (2015) demonstrated that intake of capsules containing $500 \mathrm{mg}$ cardamom powder three times a day significantly reduced the severity of NVP. ${ }^{5}$

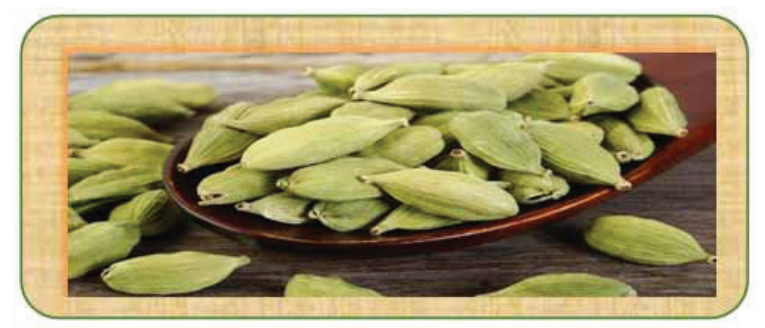

Figure 4: Ellataria cardamomum.

\section{Cydonia oblonga (Quince)}

The quince is a plant of the family Rosaceae. Cydonia oblonga, known as "Behi" ( Figure 5), is an important natural product used in the treatment of NVP. ${ }^{21,22}$ In addition, it protects the fetus from abortion and is used as an appetizer. Wet and balanced in warm and cold in temperament . A clinical trial was carried out in Tehran, Iran on the effectiveness of Cydonia oblonga (quince) syrup for treatment of NVP. The results showed significantly decreased NVP in the group receiving quince syrup. No health risks or side effects are reported following the proper administration of designated therapeutic dosages..$^{24,30}$

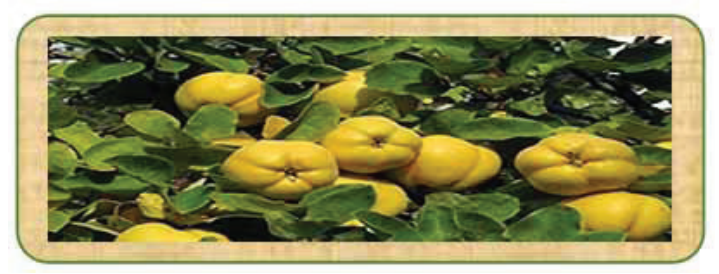

Figure 5: Cydonia oblonga.

\section{CONCLUSION}

Unani scholars have taken rational steps based on the observations. They believed that three basic steps, i.e. lifestyle modification, nutrition and medicinal herbs, had great effects on NVP treatment. Therefore, this research can provide valuable information on the clinical use of herbal medicines in NVP and prepares the ground to investigate their potential medicinal use.

\section{Author's view}

Long-term use of traditional medicines may indicate their efficacy, but it is recommended to conduct scientific studies to confirm their efficacy and safety. Scientific studies on these Unani medicines during pregnancy are required to determine their safety.

\section{REFERENCES}

1. Balikova M, Buzgova R. Quality of women's life with nausea and vomiting during pregnancy. Osetrovatelstvi a Porodni Asist 2014; 5(1): 29-35.

2. Niebyl NR. The pharmacologic management of nausea and vomiting during pregnancy. J Family Pract 2014; 63(02): S31S38.

3. Anonymous. The management of nausea and vomiting of pregnancy and hyperemesis gravidarum. RCOG Green-top guideline No. 69. 2016:1-27.

4. Khresheh R. How women manage nausea and vomiting during pregnancy: a Jordian study. Midwifery 2011;27(1):42-45.

5. Ozgoli G, Naz MSG. Effects of complementary medicine on nausea and vomiting in pregnancy. A systematic review. Int J Prev Med 2018;9:75.

6. Bustos M, Venkataramanan R, Caritis S. Nausea and vomiting of pregnancy- What's new? Auton Neurosci Basic Clin 2017;202:62-72.

7. Gill SK. Investigating sources of variability in pharmacological response in nausea and vomiting of pregnancy. Doctoral Thesis, Departmet of Pharmacology, University of Toronto. 2010:17-20.

8. Heitmann K. Treatment of nausea and vomiting during pregnancy. Eur J Clin Pharmacol 2016; 72:593-604.

9. Magee L, Shrim A, Koren G. Diagnosis and management of nausea and vomiting in pregnancy. Fetal Mater Med Rev 2006;17:145-167.

10. Lee N, Saha S. Nausea and vomiting of pregnancy. Gastroenterol Clin N Am 2011;42:309-334.

11. Chartatos A. Nausea and vomiting in pregnancy and the impact upon dietary intakes and birth outcomes - a study performed in the Norwegian Mother and child cohort study. Master Thesis, Department of Nutrition, University of Oslo. 2011:1-15.

12. Mylonas L, Gingelmaier A, Kainer F. Nausea and vomiting in pregnancy. Dtsch Arzteb 1. 2007;104(25):A1821-1826.

13. Qurshi HKM. Jamiul Hikmat. New Delhi: Idara kitab-us- shifa; 2011; 1145:725-727.

14. Khan MA. Akseere Azam (Urdu translation by Kabeeruddin). New Delhi: Idara Kitab-us-Shifa; 2011.

15. Qamri AMH. Ghana Muna. New Delhi: Markazi council baraye tahqeeqat tibbe Unani; 2008.

16. Sina I. Al Qanoon fit tib. Vol 3. ( Urdu translation by Kantoori GH). New Delhi: Idara Kitab-us-Shifa; 2007. 
17. Taylor T. Treatment of nausea and vomiting in pregnancy. Aus Prescr 2014;37:42-45.

18. Anderka M, Mitchell AA, Louik C, Werler MM, Diaz SH, Rasmussen SA. Medications used to treat nausea and vomiting of pregnancy and the risk of selected birth defects. Birth Defect Res A Clin Mol Teratol 2012;94:22-30.

19. Arsenoult AY, Lane CA. The management of nausea and vomiting of pregnancy. SOGC clinical practice guideline. J Obstet Gynaecol Can 2002;24(10):817-823.

20. Qarshi AA. Afada Kabeer majmal. Translated by Kabiruddin Hk. Deoband: Faisal publication Jamia masjid; YNM. 157.

21. Razi ABZ. Kitabul H. New Delhi: CCRUM, 2001;9.

22. Jurjani AH. Dakheera Khwarzam Shahi (trans: Khan HH). New Delhi: Idara kitab-us- shifa; 2010.

23. Batista ALA, Lins RDAU, de Souza Coelho R, do Nascimento Barbosa D, Belém NM, Celestino FJA. Clinical efficacy analysis of the mouth rinsing with pomegranate and chamomile plant extracts in the gingival bleeding reduction. Complement Ther Clin Pract 2014;20(1):93-98.

24. Ghani HN. Khazainul adviya. New Delhi: Idara kitab-us-shifa; YNM.
25. Aghili Khorasani M. Khulașat al-ḥikmah. Qom: Esmailian publications 2006(2):147.

26. Arzani M. Mufarrih al-qulub. Tehran, Almaee publications 2012: 860 .

27. Abdolhosseini S, Hashem-Dabaghian F, Mokaberinejad R, Sadeghpour O, Mehrabani M. Effects of Pomegranate and Spearmint Syrup on Nausea and Vomiting During Pregnancy: A Randomized Controlled Clinical Trial. Iranian Red Crescent Med J 2017;19(10):e13542.

28. Nazamuddin WA, Jahan A, Tanveer AM, Iqbal NM, Khan AM. Gulnar (flower of Punica granatum lin): precious medicinal herb of Unani medicine- an overview. Int J Curr Res Rev. 2013; 5(20):16-21

29. Yavari KP, Safajou F, Shahnazi M, Nazemiyeh H. The effect of lemon inhalation aromatherapy on nausea and vomiting of pregnancy: A double-blinded, randomized, controlled clinical trial. Iran Red Crescent Med J 2014;16:e14360.

30. Abdolhosseini S, Dabaghian FH, Mehrabani M, Mokaberinejad R. A Review of Herbal Medicines for Nausea and Vomiting of Pregnancy in Traditional Persian Medicine. GMJ. 2017;6(4):281-90. 